\title{
A Study of Banking Stocks in India to Develop a Model for Prudent Investment
}

\author{
P.R. Ramakrishnan", Badri Toppur \\ Rajalakshmi School of Business, India
}

Copyright $(2016$ by authors, all rights reserved. Authors agree that this article remains permanently open access under the terms of the Creative Commons Attribution License 4.0 International License

\begin{abstract}
Investments in stock markets are often volatile, uncertain, complex and ambiguous (VUCA). Can we overcome an investment decision impasse, by adopting suitable research in a particular industry with the probable risk and uncertainty embedded? This critical thinking has triggered the analysis described in this paper; the fast growing banking sector has been chosen for the study. The financial result published by the various banks up to the year ending December 2014 has been taken for our scrutiny. Furthermore, a sample of forty commercial banks listed in the schedule of Reserve Bank of India and listed with National Stock Exchange (NSE) has been taken for analysis. A non-linear portfolio optimization model has been developed that can be used by investors to park their surplus funds in Indian banking stock. This model variant allows selection of various financial ratios such as Net Interest Margin (NIM) and Non-Performing Assets (NPA) to serve as a proxy for the expected return. In addition, statistical comparisons between public sector banks and private sector banks have been conducted across important financial ratios. These tests show that private sector banks are more efficient than public sector banks when considering Return on Assets (ROA) and Net Interest Margin (NIM), but are comparable on Return on Equity (ROE).
\end{abstract}

Keywords Portfolio Optimization, Return on Assets, Rate of Return, Net Interest Margin, Non-performing Assets

\section{Introduction}

Economies like India, which offer immense growth potential, are emerging as favourite investment destinations for foreign institutional investors (FIIs). With a rising conviction about the performance of Indian securities, FIIs are gradually increasing their investments as Indian stocks are likely to outperform other emerging markets in the medium-term, according to some of the global fund managers. Foreign Institutional Investors and funds are investing billions of dollars in Indian stocks. Banking and financial services sector is growing rapidly in India due to government policy of financial inclusion and the accelerated growth of business. The financial performance, the cost of capital, rate of return and return on equity, and net interest margin are some of the determinants of banking stock prices. Moreover, the forces of demand and supply have direct effect on the stock prices. On the other hand, performance figures of firms, industry, and country influences the share prices. One of the major and important determinants of stock prices is volume traded in stock exchange market. Volume traded is defined as a measure of the quantity of shares that change owners for a given security or total number of shares traded. The interest rate mechanism and the statutory rates to be maintained by commercial banks as per the norms suggested by central bank periodically, also impact the price volatility among the banking stock. Provision for None-performing Assets (NPA) and the asset quality of the organized sector of financial markets has a major impact on the stock valuation.

Foreign portfolio managers have invested almost US\$ 40 billion in Indian stocks and debt in 2014 so far on expectations that economic growth will quicken and interest rates will be slashed. The oil glut is reducing inflation, making India a more attractive destination among emerging markets.

A bank makes money on the spread between the interest it pays to those from whom it raises funds and the interest it charges those who borrow from it, and from other services it offers it depositors. India is being viewed as a potential opportunity by investors, with the economy having the capacity to grow tremendously. Buoyed by exceptional support from the country's government, the FII sector in India looks set to prosper, and the outlook looks extremely promising. The banking industry in India has the potential to become the fifth largest banking industry in the world by 2020 and third largest by 2025 according to a KPMG-CII report. Over the next decade, the banking sector is projected to create up to two million new jobs, driven by the efforts of the RBI and the Government of India to integrate financial services into rural areas. Also, the traditional way of 
operations will slowly give way to modern technology. India is among the few countries where interest rates are expected to drop with fair visibility, which would attract flow from FII, as reported by experts. It is for the global community to be a part of this Make in India drive with a comfortable return on investment.

FIIs have invested US\$ 16.3 billion in Indian equities in 2014, the highest among the seven emerging markets tracked by Bloomberg. Commercial banks in India have undergone immense regulatory and technological changes since financial sector reforms in 1991. Indian commercial sector banks are faced with increasing Nonperforming assets and rising costs as a result of regulatory requirements, financial and technological innovation, increasing capital adequacy and challenges of the recent financial crisis. These changes had a dramatic effect on the performance of the commercial banks in India. Banking software developed by Indian corporations has become widely accepted around the globe.

The main objective of financial statements is to provide useful information to both internal and external users. Listed companies generally use financial statements as one of the major mediums of communication with stakeholders. The majority of the government banks may walk into deeper problems on account of capital required to meet the Basel-III norms and provide for bad and restructured loans stipulated by the RBI norms. Significant increase in the quantity and quality of capital is being insisted as per the revised norms. Stock market regulators and accounting standards setters try to improve the quality of financial statements in order to increase the transparency level in financial reporting as noted by Vishnani and Shah [1].

The most basic factors that influence price of equity share are demand and supply factors. If most people start buying, then prices move up and if people start selling prices go down. Government policies, firm's and industry's performance and potentials have effects on demand behavior of investors, both in the primary and secondary markets. The factors affecting the price of an equity share can be viewed from the macro and microeconomic perspectives. Macro-economic factors like how the economy is performing, and government regulations. Then there may be other factors like demand and supply conditions which can be influenced by the performance of the company. The objectives of this paper are primarily about getting an idea about the factors affecting the equity return of studied banks stock. Secondarily, to identify whether there is a significant relationship between market return and the price of equity shares with special reference to Banking sector.

\section{Twin Objectives of the Study}

The primary objective was to develop a portfolio model for forty Indian banks from both the private sector and the public sector based upon the Markowitz model [2]. This optimization model distinguishes well-performing banks stocks from poor performing ones to identify investment in such banks equity shares for better return to the investors in secondary market through stock exchanges and global FIIs.
The secondary objective of the study is to evaluate the financial performance of commercial banks from 2010 to 2014, by making a statistical comparison among the listed public sector and private sector banks using selected financial ratios. This aims at providing an overall subjective assessment of the current status and financial performance of banking sector in India. We ascertain if there is any significant difference of profitability means among public and private sector bank groups using statistical tests in a manner inspired by Ally [3]. This paper has been structured as follows. Section one is this introductory one. Section two contains the literature review. Section three elaborates about the data sources, and the statistical and operational research tools applied for the analysis. Section four draws conclusions about the study.

\section{Literature Review}

Several studies attempt to investigate the factors that influence the efficiency of banks. Some studies examine only bank-specific factors and others examine both bank-specific attributes and environmental determinants. While bank performance has been traditionally evaluated on the basis of financial ratios, advances in operational research (O.R.) applications of data envelopment analysis (DEA) in the estimation of bank efficiency and productivity growth, has been done by T. Cronje [4]. DEA is a mathematical programming technique, pioneered by Charnes et al., for the development of production frontiers and the measurement of efficiency relative to these frontiers [5].The best-practice production frontier for a sample of banks, according to Thanassoulis, is constructed through a piecewise linear combination of actual input-output correspondence set that envelops the input-output correspondence of all banks in the sample [6]. Each bank is assigned an efficiency score between 0 and 1 . The scores are only relative to the banks in the sample, with higher scores indicating a more efficient bank.

Zawadi Ally, in his study on banking sector in Tanzania, published in 2013, has observed that banks were adequately capitalized, profitable and remained in a sound position [3]. The study found that, there is no a significant means difference of profitability among of peer banks groups in term of ROA, however, a significance differences among banks group existed in term of ROE and NIM.

The major weakness of these early studies was their inability to isolate the effect of earnings changes from other information released. Alam et al. in their study on the performance of banks had considered the following variables for analysis. (1) Net income to total assets; (2) Net Loan losses to adjusted assets; (3) Net loan losses to total loans; (4) non-performing loans to total assets; (5) (net loan losses + provisions) to net income [7]. Lanine and Vander Vennet in their analysis of banks about credit rating had used the following variables (1) Net income/total assets, (2) Liquid assets/total assets, (3) Government debt securities/total 
assets, (4) Capital / total assets, (5) (Overdue loans + overdue promissory notes)/ total loans, (6) Total loans/total assets, (7) Log (total assets) [8].

Horobet et al. describes that stock market index is positively connected with the effective exchange rate, money supply, the interest rate, and substitutes in the development procedure [9]. Wang, et al. establishes that large firms react quicker to new information as compared to small firms [10]. Since share prices are advance looking, they present a sole evidence of changing in investors views about the prospect forecast of companies. Glaser and Weber investigate that the confidence level of different investors can be measured with several scores [11]. High risks will be taken by investors after huge profits and they purchase high risks securities. Engle and Rangel claim that high frequency collective stock instability has both a short-run and long-run element, and propose that the long-run factor is connected to the business cycle [12].

Dangwal and Kapoor evaluated the financial performance of nationalized banks in India and assessed the growth index value of various parameters through overall profitability indices [13]. Hayati investigated the Financial Statement Report and its Impact on Stock Price (case study on banking sector) in Indonesia [14]. This study found that the financial statements are the main indicator to estimate more precise and rational measuring the company's future prospects. The market will quickly react to the information in the financial statements. Issuers are late in delivering financial statements that gave a bad impression to the investors, which in turn weaken investor's confidence in the company. The reaction will appear in the stock price.

Tsz-Kin Chung et al., explains share price disparity due to uncertainty from China stock markets [15]. They have used data of 44 dual listed companies over the sample period from 2006-2010. Independent variables are selected by them as determinants of disparity equity values, debts, time to maturity and risk free interest rate. To analyze the relationship between price disparity and parameter uncertainty they have used panel regression analysis. According to their analysis parameter uncertainty is a strong factor on share price disparity. They have reported that parameter uncertainty is also related with other variables.

\subsection{Banking Financial Performance Indicators}

Profit is the ultimate goal of commercial banks. All the strategies designed and activities performed thereof are meant to realize this grand objective. However, this is in addition to the other social obligation. Commercial banks could also have additional social and economic goals. However, the intention of this study is related to the first objective, profitability. To measure the profitability of commercial banks there are variety of ratios used of which Return on Asset, Return on Equity and Net Interest Margin are the important ones, as mentioned by Murthy and Sree [16].

\subsubsection{Return on Equity ROE)}

\section{ROE $=$ Net Profit after Taxes $/$ Equity Capital}

ROE is a financial ratio that refers to how much profit a company earned compared to the total amount of shareholder equity invested or found on the balance sheet. ROE is what the shareholders look in return for their investment. A business that has a high return on equity is more likely to be one that is capable of generating cash internally. Thus, the higher the ROE the better the company is in terms of profit generation. It is further explained by Khrawish that ROE is the ratio of Net Income after Taxes divided by Total Equity Capital [17]. It represents the rate of return earned on the funds invested in the bank by its stockholders. ROE reflects how effectively a bank management is using shareholders' funds. Thus, it can be deduced from the above statement that the better the ROE the more effective the management in utilizing the shareholders capital.

\subsubsection{Return on Asset (ROA)}

\section{ROA $=$ Net Profit after Taxes / Assets}

ROA is also another major ratio that indicates the profitability of a bank. The return on assets, provide information on how efficiently a bank is being run because it indicates how much profits are generated by each dollar of assets. It is a ratio of Income to its total asset. It measures the ability of the bank management to generate income by utilizing company assets at their disposal. In other words, it shows how efficiently the resources of the company are used to generate the income. It further indicates the efficiency of the management of a company in generating net income from all the resources of the institution. A higher ROA shows that the company is more efficient in using its resources [18].

\subsubsection{Net Interest Margin (NIM)}

\section{NIM = (Interest Income - Interest Expenses) / Assets}

Net Interest Margin is a measure of the difference between the interest income generated by banks and the amount of interest paid out to their depositors relative to the amount of their lenders. It is usually expressed as a percentage of what the financial institution earns on loans in a specific time period and other assets minus the interest paid on borrowed funds divided by the average amount of the assets on which it earned income in that time period (the average earning assets). The Net Interest Margin variable is defined as the net interest income divided by total earnings assets as per Gul et al. [19]. Net interest margin measures the gap between the interest income the bank receives on loans and securities and interest cost of its borrowed funds. It reflects the cost of bank intermediation services and the efficiency of the bank. The higher the net interest margin, the higher the bank's profit and the more stable the bank is. Thus, it is one of the key measures of bank profitability. However, a higher net interest margin could reflect riskier lending practices 
associated with substantial loan loss provisions, as noted by Khrawish.

Table 1. RBI data

\begin{tabular}{|l|r|}
\hline Capital infusion by govt in PSBs & In Rs crore \\
\hline FY09 & 1,900 \\
\hline FY10 & 1,200 \\
\hline FY11 & 20,117 \\
\hline FY12 & 12,000 \\
\hline FY13 & 12,517 \\
\hline FY14 & 14,000 \\
\hline FY15* & 11,200 \\
\hline FY16* & 7,940 \\
\hline *proposed & \\
\hline
\end{tabular}

Reserve Bank data reflects that state-run banks' capital needs to comply with Basel-III regulations may overshoot the earlier estimate of Rs 2.4 trillion, and a huge capital requirement and the banks should generate from other sources and capital infusion by government may not cover the huge demand for funds. A bank's real capital worth is evaluated after taking into account the riskiness of its assets. It was earlier hoped that the capital would provide banks with a comfortable cushion against insolvency, thereby ensuring market stability. In the wake of the introduction of prudential regulation as an integral part of financial sector reforms in India, there has been a growing debate as to whether capital adequacy requirements are the best means to regulate the banking system. Basel III norms suggest the quality and quantity of capital that an Indian bank should maintain. Under these circumstances all the commercials are very keen on approaching the equity market to augment their capital base and expecting participation from FII and Indian investors to respond. The study aims to provide a model for the investors including the foreign institutional investors to identify the portfolio they may choose while investing their money in Indian banking stock with a risk management.

\section{Portfolio Optimization}

We built a minimum variance portfolio model for the forty banks registered on the National Stock Exchange (NSE) by forming the excess return matrix $\mathrm{X}$ and then subsequently the variance-covariance matrix $\mathrm{X}^{t} \mathrm{X}$ as demonstrated by Wright [20]. The non-linear mathematical programming model, for $\mathrm{n}$ bank stocks, is:

\section{Minimize $\mathrm{YAY}^{\mathrm{t}}$}

Subject to:

$$
y_{1}+y_{2} \cdots+y_{n}=
$$

$$
\begin{gathered}
E(Y) \geq R \\
A=X^{t} X \\
y_{i} \geq 0 \text { for } i=1,2, \ldots, n
\end{gathered}
$$

In the above model, $\mathrm{YAY}^{\mathrm{t}}$ is the portfolio variance being minimized, where $\mathrm{A}=\mathrm{X}^{t} \mathrm{X}$ is the variance-covariance matrix obtained from the bank sector stock data. The variables $y_{i}$ are the percent allocation of the excess return invested in the different banks. $\mathrm{E}(\mathrm{Y})$ is the expected value of the portfolio, and $\mathrm{R}$ is the minimum expected return from the investment. The monthly opening and closing prices for 2.5 years were obtained from the Economic Times website [21]. These thirty observations for forty banks were used to form the returns matrix from which we obtain the excess return matrix $\mathrm{X}$, by subtracting the average return for each stock from the monthly observation. The monthly return is obtained from the ratio of the closing price of the stock to the opening price expressed as a percentage above or below hundred. This model was solved using Frontline's Solver for Excel. The minimum variance optimization suggested that thirty one out of the forty banks required no investment. Out of the nine for which there was any allocation, HDFC bank had the largest share with $42.78 \%$ of the investment followed by South Indian Bank with $17.08 \%$. The percentage investment is shown in the pie-chart. The portfolio variance was minimized with a minimum expected return of $10 \%$. This recommended allocation is stable with expected return ranging from $10 \%$ up to $25 \%$.

\subsection{Forming the Covariance Matrix with other Financial Ratios}

The question that we wished to address, was, how is the portfolio selection affected by the choice of financial ratio that is used as a proxy for return? Instead of the ratio of the closing and opening prices, we considered taking Net Interest Margin (NIM) as a proxy for the return. NIM is the net interest income earned by the bank on its average earning assets. These assets comprises of advances, investments, balance with the RBI and money at call. As such it is calculated as,

$\mathrm{NIM}=($ Interest income - interest expenses $)$ / average earning assets.

At the Equity Master site, we found the NIM calculated for five consecutive years for 33 out of the 40 banks that are listed on the stock exchange. We calculated a variance-covariance matrix based on NIM in a fashion similar to the matrix calculation for the closing price/opening price ratio. 


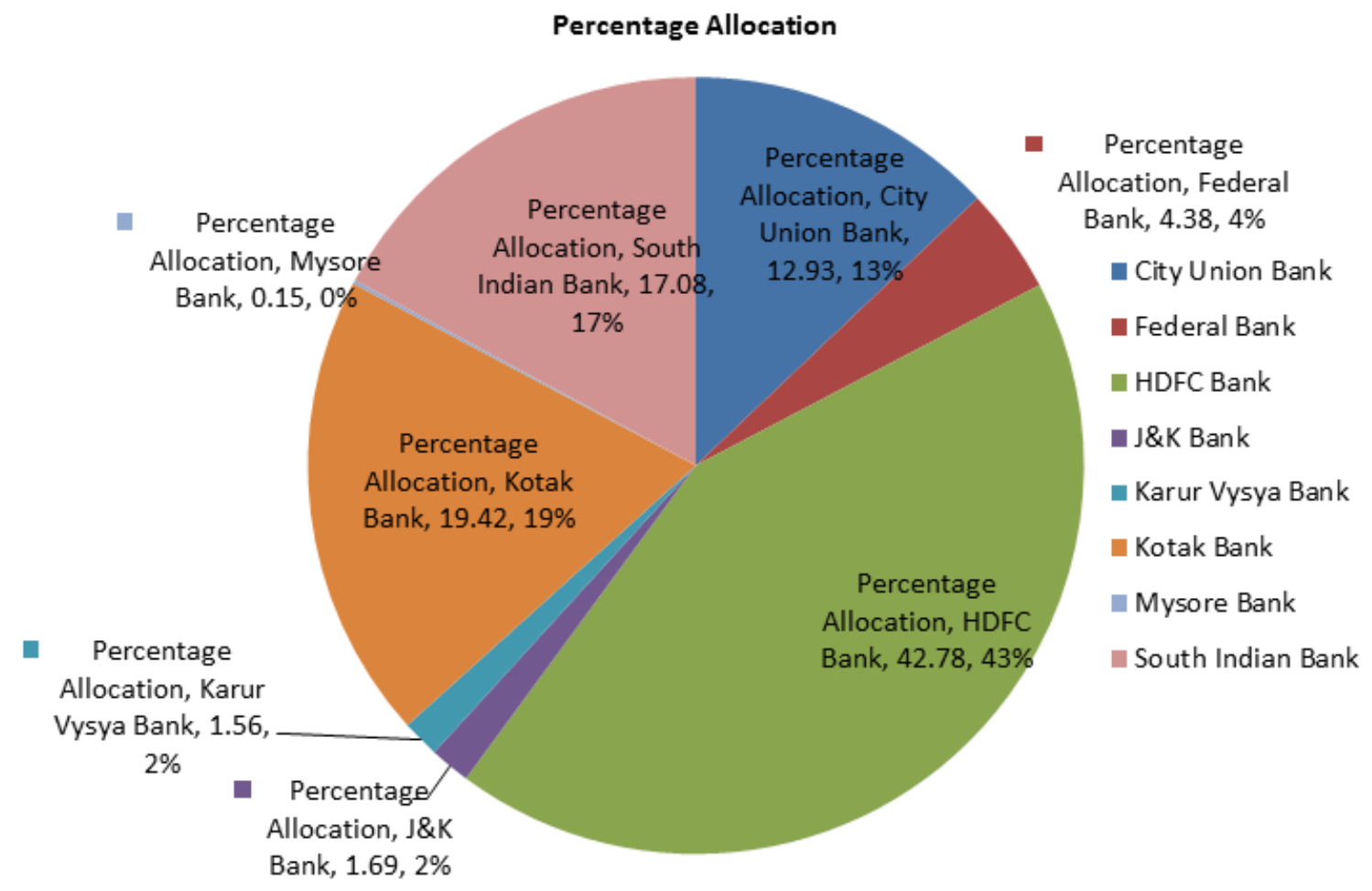

Figure 1. Percentage Allocation from Portfolio Variance Model

\section{Percentage Allocation based on NIM}

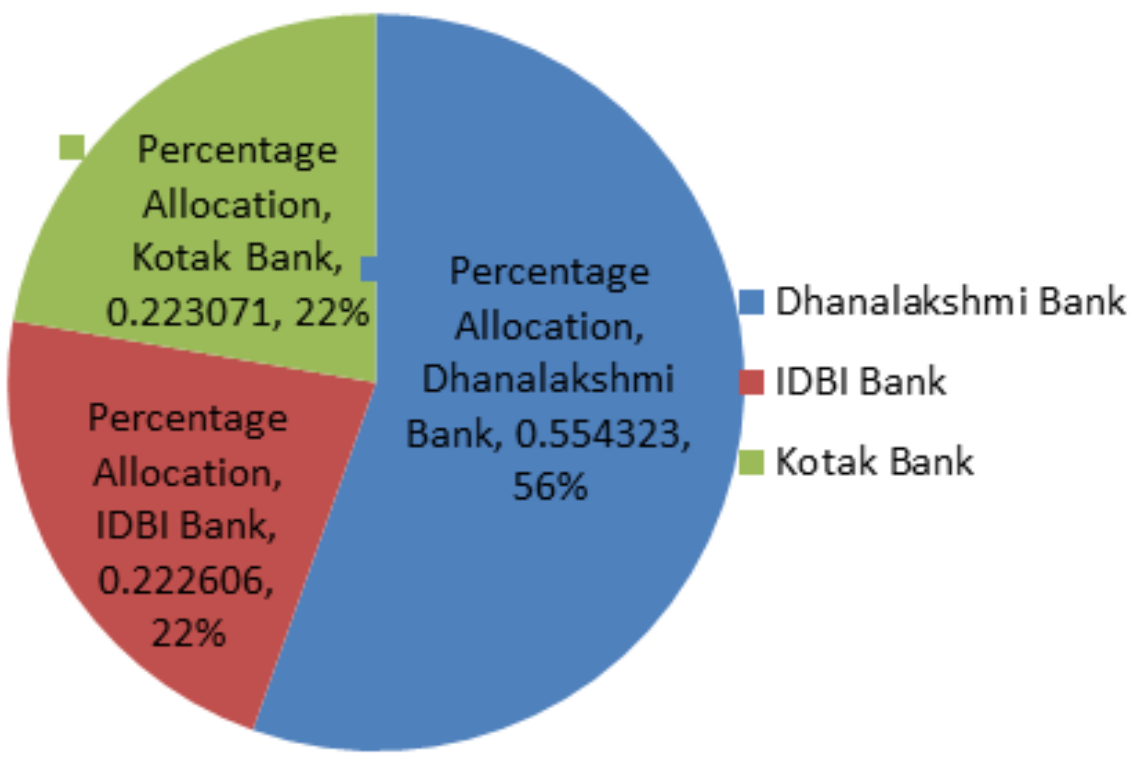

Figure 2. Allocation among three banks based on NIM 


\section{Canara Bank \\ DCBBK \\ Federal \\ $-\mathrm{IClCl}$ \\ Vijaya Bank}

\section{Percentage Allocation based on NPA}

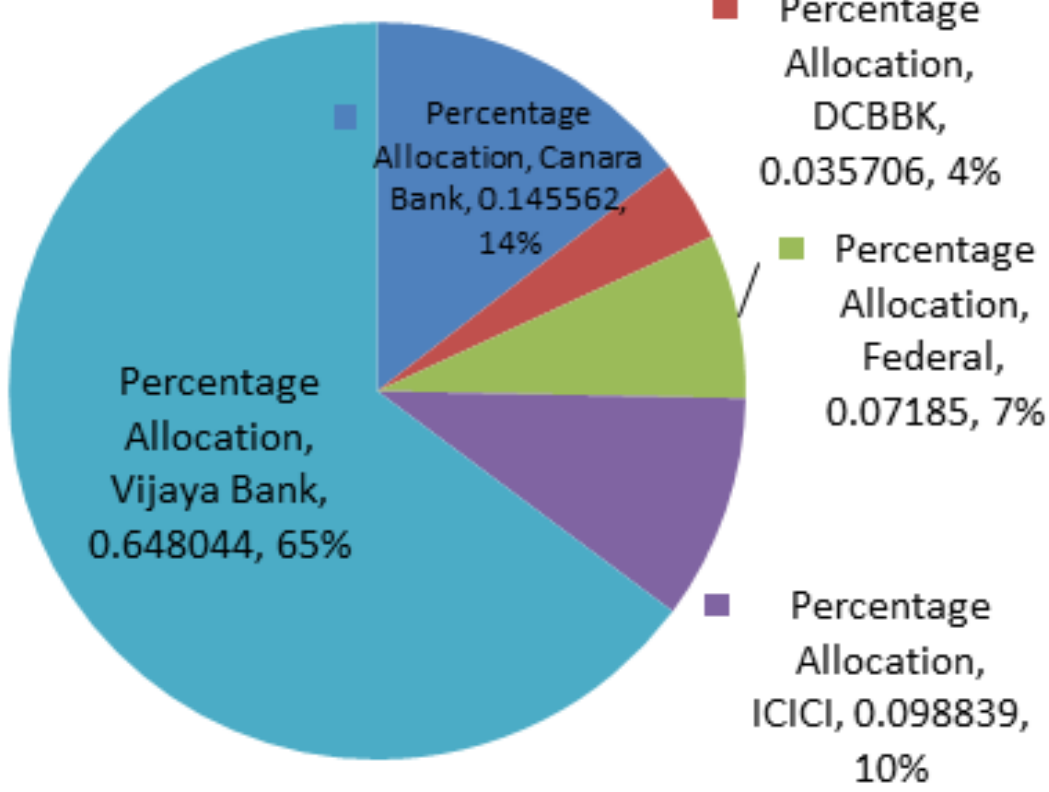

Figure 3. Percentage allocation based upon NPA

A balance sheet ratio we also considered for the variance-covariance matrix was net Non-performing Assets (NPA). Forming a variance-covariance matrix based on NPA and running a portfolio model, we obtained five banks out of thirty two that were giving good returns.

Using NIM as the financial criterion reduces the contest to three banks out of forty. Using NPA, a different set of five banks is highlighted. From these experimental results, we can conclude that the selection of financial ratio effects the allocation significantly. Depending on various behavioral factors and their risk disposition, investors can pick the financial ratio that they consider a true index of the bank's health.

\subsection{Statistical Tests Comparing Public Sector Banks with Private Sector Banks}

\subsubsection{Research Methodology}

To accomplish the second objective of the study, other relevant secondary data was used. It has been collected from bank records, published financial reports, journals, and websites. We took the much of the financial secondary data from two sources, Equity Master and Arcadia Share and Stock Brokers Pvt. Ltd. The study is chronological and covers a period from 2010 to 2014 . We used the F-test for testing equality of variances between two populations, and then the t-test for equality of two population means.

\subsubsection{Sample Size}

A sample of thirty three banks consist of public sector and private sector banks listed in BSE/NSE have been taken for analysis and the performance of these banks have been evaluated on the basis of the data released by RBI and other authorized websites in India.

Secondly, we performed extensive hypothesis testing about the equality of means between the two populations public sector banks and private sector banks. The financial ratios considered were Return on Assets (ROA), Return on Equity (ROE), and Net Interest Margin (NIM). Many other ratios are available on the company fact sheets, but we have not selected all of them for our study. The three hypotheses tested had the following null hypotheses:

$\mathrm{Ho}_{1}$ : There is no significant difference in average ROA between public and private sector banks

$\mathrm{Ho}_{2}$ : There is no significant difference in average ROE between public and private sector banks

$\mathrm{Ho}_{3}$ : There is no significant difference in average NIM between public and private sector banks

For each of this null hypothesis, the alternative hypothesis was that there is a significant difference in the average ratio between public and private sector banks. We took the financial secondary data from two sources, Equity Master and Arcadia Share and Stock Brokers Pvt. Ltd [22, 23].

For the t-tests there is an assumption of equal variances in the two populations that needs to be verified. So, first the F-test for equal variances was performed using the sample data from Equity Master, and it was evident that the variances were not equal for the two populations, public and private sector banks. When we tested the equality of variance for the data from Arcadia Share and Stock Brokers, the conclusion was that the variance was equal in the case of ROE, but different for ROA and NIM. We then performed the appropriate t-tests and at a 5\% significance level for the three parameters, using the two data sources. The result of the hypothesis test was the same. We had to reject the null 
hypothesis of equal means for Return on Assets and NPA. Only for Return on Equity was the null hypothesis acceptable. This is interesting, that the disparity between public sector banks and private sector banks is not statistically significant in the case of Return on Equity. In Tables 2 and 3 we present, for the financial ratio (ROA) the results of the F-test for equal variances and the t-test for equal means (assuming unequal variances). The $\mathrm{p}$-value is small at the 5\% significance level and we can reject the null hypothesis for both equality of variances and equality of means $\mathrm{Ho}_{1}$.

In Tables 4 and 5 we have the tests for ROE. The p-value for the test about equality of variances is small at $5 \%$ significance level, and we can reject the null hypothesis of equality. The p-value for the equality of ROE means is however not small at 0.481079164 , and we must accept the null hypothesis $\mathrm{Ho}_{2}$. Therefore public sector banks are comparable in efficiency to private sector banks, on the basis of ROE.

Table 2. (ROA) Equity Master

\begin{tabular}{|c|c|c|}
\hline \multicolumn{2}{|c|}{ F-Test Two-Sample for Variances } \\
\hline & Variable 1 & 1.126666667 \\
\hline Mean & 0.75 & 0.261066667 \\
\hline Variance & 0.063682 & 15 \\
\hline Observations & 18 & 14 \\
\hline Df & 17 & \\
\hline F & 0.243931 & \\
\hline $\mathrm{P}(\mathrm{F}<=$ f) one-tail & 0.003554 & \\
\hline F Critical one-tail & 0.429378 & \\
\hline
\end{tabular}

Table 3. (ROA) Equity Master

\begin{tabular}{|c|c|c|}
\hline \multicolumn{2}{|c|}{$\mathrm{t}$-Test: Two-Sample Assuming Unequal Variances } \\
\hline & Variable 1 & Variable 2 \\
\hline Mean & 0.75 & 0.261066667 \\
\hline Variance & 0.063682 & 15 \\
\hline Observations & 18 & \\
\hline Hypothesized Mean Difference & 0 & \\
\hline Df & 20 & \\
\hline $\mathrm{t}$ Stat & -2.60282 & \\
\hline $\mathrm{P}(\mathrm{T}<=\mathrm{t})$ one-tail & 0.008511 & \\
\hline $\mathrm{t}$ Critical one-tail & 1.724718 & \\
\hline $\mathrm{P}(\mathrm{T}<=\mathrm{t})$ two-tail & 0.017023 & \\
\hline $\mathrm{t}$ Critical two-tail & 2.085963 & \\
\hline
\end{tabular}

Table 4. (ROE) Equity Master

\begin{tabular}{|c|c|c|}
\hline \multicolumn{2}{|c|}{ F-Test Two-Sample for Variances } & Variable 2 \\
\hline & Variable 1 & 13.56266667 \\
\hline Mean & 13.47666667 & 36.45896381 \\
\hline Variance & 14.11521176 & 15 \\
\hline Observations & 18 & 14 \\
\hline Df & 17 & \\
\hline F & 0.387153399 & \\
\hline $\mathrm{P}(\mathrm{F}<=\mathrm{f})$ one-tail & 0.032848232 & \\
\hline $\mathrm{F}$ Critical one-tail & 0.429377673 & \\
\hline
\end{tabular}


Table 5. ROE (Equity Master)

\begin{tabular}{|c|c|c|}
\hline \multicolumn{2}{|c|}{$\mathrm{t}$-Test: Two-Sample Assuming Unequal Variances } \\
\hline & Variable 1 & Variable 2 \\
\hline Mean & 13.47666667 & 36.458966381 \\
\hline Variance & 14.11521176 & 15 \\
\hline Observations & 18 & \\
\hline Hypothesized Mean Difference & 0 & \\
\hline $\mathrm{t}$ Stat & -0.04796485 & \\
\hline $\mathrm{P}(\mathrm{T}<=\mathrm{t})$ one-tail & 0.481079164 & \\
\hline $\mathrm{t}$ Critical one-tail & 1.713871517 & \\
\hline $\mathrm{P}(\mathrm{T}<=\mathrm{t})$ two-tail & 0.962158328 & \\
\hline $\mathrm{t}$ Critical two-tail & 2.068657599 & \\
\hline
\end{tabular}

Table 6. NIM (Equity Master)

\begin{tabular}{|c|c|c|}
\hline \multicolumn{2}{|c|}{ F-Test Two-Sample for Variances } & Average NIM \\
\hline & Average NIM & 2.88 \\
\hline Mean & 2.384166667 & 0.5424 \\
\hline Variance & 0.164277206 & 15 \\
\hline Observations & 18 & 14 \\
\hline Df & 17 & \\
\hline F & 0.302870955 & \\
\hline $\mathrm{P}(\mathrm{F}<=\mathrm{f})$ one-tail & 0.010785962 & \\
\hline F Critical one-tail & 0.429377673 & \\
\hline
\end{tabular}

Table 7. NIM (Equity Master)

\begin{tabular}{|c|c|c|}
\hline \multicolumn{2}{|c|}{$\mathrm{t}$-Test: Two-Sample Assuming Unequal Variances } \\
\hline & Average NIM & Average NIM \\
\hline Mean & 2.384166667 \\
\hline Variance & 0.164277206 & 0.5424 \\
\hline Observations & 18 & 15 \\
\hline Hypothesized Mean Difference & 0 & \\
\hline Df & 21 & \\
\hline $\mathrm{t}$ Stat & -2.329975134 & \\
\hline $\mathrm{P}(\mathrm{T}<=\mathrm{t})$ one-tail & 0.014931255 & \\
\hline $\mathrm{t}$ Critical one-tail & 1.720742871 & \\
\hline $\mathrm{P}(\mathrm{T}<=\mathrm{t})$ two-tail & 0.02986251 & \\
\hline $\mathrm{t}$ Critical two-tail & 2.079613837 & \\
\hline
\end{tabular}

Table 8. ROA (Arcadia)

\begin{tabular}{|c|c|c|}
\hline \multicolumn{2}{|c|}{ F-Test Two-Sample for Variances } \\
\hline & Variable 1 & 1.234154 \\
\hline Mean & 0.987222222 & 0.328452 \\
\hline Variance & 0.116527124 & 13 \\
\hline Observations & 18 & 12 \\
\hline Df & 17 & \\
\hline F & 0.354777111 & \\
\hline $\mathrm{P}(\mathrm{F}<=\mathrm{f})$ one-tail & 0.025236821 & \\
\hline F Critical one-tail & 0.420052612 & \\
\hline
\end{tabular}


In Tables 6 and 7 we have the results for the hypothesis tests on the NIM variable. The p-values are small for the test of equal variance and equal means (assuming unequal variances), and so we reject the null hypothesis Ho3.

We ran the same battery of tests on the financial ratios obtained from the Arcadia Shares and Stock database. The results of these tests are presented in Tables 8 to 12. From Tables 8 and 9 we see that the p-value for the test is small and we must again reject the null hypothesis Hol of equality of mean ROA (assuming unequal variances).

Tables 10 and 11 show that the p-value is not small at the 5\% significance level, and we must accept the null hypothesis of equal variances, and also the null hypothesis Ho2 of equal means for ROE between the two populations. This result corroborates what we obtained from the EquityMaster database. The public sector banks are comparable in efficiency to private sector banks on the basis of the ROE financial ratio.

Tables 12 and 13 show the results of the hypothesis test conducted on the NIM financial ratio taken from the Arcadia database. The p-values for the two tests are small at the 5\% significance level and we must conclude that the population variances are unequal, and furthermore the mean value of NIM is different between the two populations. We are thus accepting $\mathrm{Ho} 3$ as we did with the Equity Master data.

Table 9. ROA (Arcadia)

\begin{tabular}{|c|c|c|}
\hline \multicolumn{2}{|c|}{ t-Test: Two-Sample Assuming Unequal Variances } \\
\hline & Variable 1 & 1.23415385 \\
\hline Mean & 0.799583 & 0.32845164 \\
\hline Variance & 0.061513 & 13 \\
\hline Observations & 18 & 15 \\
\hline Hypothesized Mean Difference & -2.56595 & \\
\hline Df & 0.010753 & \\
\hline $\mathrm{t}(\mathrm{T}<=\mathrm{t})$ one-tail & 1.75305 & \\
\hline $\mathrm{t}$ Critical one-tail & 0.021506 & \\
\hline $\mathrm{P}(\mathrm{T}<=\mathrm{t})$ two-tail & 2.13145 & \\
\hline $\mathrm{t}$ Critical two-tail & & \\
\hline
\end{tabular}

Table 10. ROE (Arcadia)

\begin{tabular}{|c|c|c|}
\hline \multicolumn{3}{|c|}{ F-Test Two-Sample for Variances } \\
\hline & Variable 1 & 15.88615 \\
\hline Mean & 15.80156 & 24.26709 \\
\hline Variance & 15.19299 & 13 \\
\hline Observations & 18 & 17 \\
\hline Df & 0.626074 & \\
\hline $\mathrm{F}$ & 0.183593 & \\
\hline $\mathrm{P}(\mathrm{F}<=\mathrm{f})$ one-tail & 0.420053 & \\
\hline
\end{tabular}

Table 11. ROE (Arcadia)

\begin{tabular}{|c|c|c|}
\hline \multicolumn{2}{|c|}{ t-Test: Two-Sample Assuming Equal Variances } & Variable 1 \\
\hline Mean & 15.80155556 & 15.88615385 \\
\hline Variance & 15.19299273 & 18.26709431 \\
\hline Observations & 18.94779338 & 13 \\
\hline Pooled Variance & 0 & \\
\hline Hypothesized Mean Difference & 29 & \\
\hline Df & -0.053396077 & \\
\hline $\mathrm{t}$ Stat & 0.478891236 & \\
\hline $\mathrm{P}(\mathrm{T}<=\mathrm{t})$ one-tail & 1.699126996 & \\
\hline $\mathrm{t}$ Critical one-tail & 0.957782473 & \\
\hline $\mathrm{P}(\mathrm{T}<=\mathrm{t})$ two-tail & 2.045229611 & \\
\hline $\mathrm{t}$ Critical two-tail & & \\
\hline
\end{tabular}


Table 12. NIM (Arcadia)

\begin{tabular}{|c|c|c|}
\hline \multicolumn{2}{|c|}{ F-Test Two-Sample for Variances } & Variable 2 \\
\hline & Variable 1 & 2.883692 \\
\hline Mean & 2.356667 & 0.519033 \\
\hline Variance & 0.152189 & 13 \\
\hline Observations & 18 & 12 \\
\hline Df & 17 & \\
\hline F & 0.293216 & \\
\hline $\mathrm{P}(\mathrm{F}<=\mathrm{f})$ one-tail & 0.010645 & \\
\hline $\mathrm{F}$ Critical one-tail & 0.420053 & \\
\hline
\end{tabular}

Table 13. NIM (Arcadia)

\begin{tabular}{|c|c|c|}
\hline \multicolumn{2}{|c|}{$\mathrm{t}$-Test: Two-Sample Assuming Unequal Variances } \\
\hline & Variable 1 & 2.883692308 \\
\hline Mean & 2.356667 & 0.519033231 \\
\hline Variance & 0.152189 & 13 \\
\hline Observations & 18 & \\
\hline Hypothesized Mean Difference & 0 & \\
\hline Df & 17 & \\
\hline $\mathrm{t}$ Stat & -2.39605 & \\
\hline $\mathrm{P}(\mathrm{T}<=\mathrm{t})$ one-tail & 0.014176 & \\
\hline $\mathrm{t}$ Critical one-tail & 1.739607 & \\
\hline $\mathrm{P}(\mathrm{T}<=\mathrm{t})$ two-tail & 0.028352 & \\
\hline $\mathrm{t}$ Critical two-tail & 2.109816 & \\
\hline
\end{tabular}

\section{Conclusions}

In this paper, the authors have provided a commentary about the positive trend of increasing foreign investment in the Indian industry. To complement the information that is already available to investors, we have presented a quantitative analysis of a large sample of public sector and and private sector banks that are operative in India. A portfolio selection model highlights the banks giving the most return on investment. We have considered various financial ratios, other than closing price/opening price as a proxy to the "return" variable. Investors, who have been following the discussion in behavioral finance, will appreciate these options in addition to the standard model. As a secondary objective of the study, we have performed a statistical test comparing the public sector banks with the private sector banks across the financial ratios. These statistical tests, demonstrate that private sector banks are more efficient than public sector banks when considering Return on Assets (ROA) and Net Interest Margin (NIM) financial ratios, but are comparably efficient when we examine the Return on Equity (ROE) financial ratio.

\section{REFERENCES}

[1] Vishnani S. and Shah B. K. (2008) Value Relevance of
Published Financial Statements - With special Emphasis on Impact of Cash Flow Reporting, International Research Journal of Finance and Economics, Volume 17.

[2] Markowitz, Harry, Portfolio Selection, The Journal of Finance, Volume 7, No. 1, March 1952, pp. 77-91.

[3] Zavadi, Ally (2013) Comparative Analysis of Financial Performance of Commercial Banks in Tanzania. Research Journal of Finance and Accounting, Volume 4, Number 19.

[4] [Cronje, T, Assessing the relative efficiency management of South African banks. Management Dynamics 16 pp 11-23. (2007)

[5] Charnes, A, Cooper, W.W., Lewin, A. Y. and Seiford, L. M. (1994) Data envelopment analysis: theory, methodology and application. Boston: Kluwer Academic Publishers.

[6] Thanassoulis, Emmanuel. An Introduction to the Theory and Application of Data Envelopment Analysis, KAP/Kluwer, Norwell Massachusetts. (2001)

[7] Alam H.M., Raza A, Akram M.A., "financial performance comparison of public vs. private banks: The case of commercial banking sector of Pakistan." Int. J. Bus. Soc. Sci., 2(11): 56-64, 2011.

[8] Lanine G., Vander Vennet R., (2006), Failure prediction in the Russian bank sector with logit and trait recognition models, Expert Systems with Applications, 30, 463-478.

[9] Horobet, A., Dumitrescu, Sorin et al., On the Causality Between Stock Prices and Exchange Rates: Evidence from Romania (February 12, 2009). 
[10] Wang, Lim, "Effects of Macroeconomic Factors on Share Prices" Journal of International Finance \& Economics, 10, 2010, pp. 113-123, (2010).

[11] Glaser, M., Weber, M. (2007). Overconfidence and trading volume. Geneva Risk and Insurance Review, 32(1), 1-36. http://dx.doi.org/10.1007/s10713-007-0003-3

[12] Engle, R., and J.G. Rangel (2008), "The Spline-GARCH Model for Low Frequency Volatility and its Global Macroeconomic Causes," Review of Financial Studies, 21, $1187-1222$

[13] Dangwal, R. C., and Reetu Kapoor (2010), "Financial Performance of Nationalised Banks ", NICE Journal of Business, Vol. 5, No. 2

[14] Hayati N R. (2010), Financial Statement Report and its Effect on Stock Price, Widyatama University, Volume 09, Spring

[15] Tsz-Kin, Chung, Ka-Fai Li, Cho-Hoi Hui, Explaining Share Price Disparity with Parameter Uncertainty: Evidence from Chinese A- and H-Share, Journal of Banking \& Finance $37 \mathrm{pp}$. 1073-1083, (2013).

[16] Rama Murthy, Y. Sree (2003) A Study on Financial Ratios of Major Commercial Banks, Research Studies, College of Banking \& Financial Studies, Sultanate of Oman

[17] Khrawish, H. A. (2011) Determinants of Commercial Banks Performance: Evidence from Jordan, International Research Journal of Finance and Economics. Zarqa University,5(5), 19-45

[18] Wen, W. (2010) Ownership Structure and Banking Performance: New Evidence in China Universitat Autònoma de Barcelona Department D'economia de L'empresa, 2010.

[19] Gul, S., Irshad, F., Zaman, K. (2011), Factors Affecting Bank Profitability in Pakistan. The Romanian Economic Journal, 39, 61-87.

[20] Wright, Colby, https://www.youtube.com/watch?v=ZfJW3ol 2FbA, 2012.

[21] Economic Times https://ecdonomictimes.indiatimes.com, 2015

[22] Equity Master, https://www.equitymaster.com, 2015

[23] Arcadia Stock, https://www.arcadiastock.com, 2015

[24] Suraj, E. S. Value Investing Using Price Earnings Ratio for Public Sector Bank Stocks in India, Indian Journal of Research in Management, Business and Social Sciences, Volume 2, Issue 2, June 2014.

[25] Goel, Cheenu, Chitwan Bhutani Rekhi (2013) A Comparative Study on the Performance of Selected Public Sector Banks and Private Sector Banks in India. Journal of Business Management and Social Sciences Research, Volume 2, Number 7.

[26] Charumathi B and Suraj E. S. (2014) Comparing Stock Valuation Models for Indian Bank Stocks. International Journal of Accounting and Taxation, Volume 2, Number 2, pp. 111-127.

[27] Menike M.G.P.D. and Wang Man, Stock Market Reactions to the Release of Annual Financial Statements - Case of the Banking Industry in Sri Lanka, European Journal of Business and Management, Volume 5, No. 31, 2013 